\title{
Time as Told: telling the past in Kyrgyzstan
}

Dr Stephanie Bunn, University of St Andrews

Abstract: This paper addresses Kyrgyz 'time-telling', exploring how Kyrgyz herders and villagers 'tell' of their past and their experience of time through genealogies, family stories and epic poetry. The author takes a phenomenological approach to show how the telling of different forms of narrative, interweaving history, myth and story, reveal the life within the past, as genres mesh, and not always seamlessly. She argues that the lived experience of 'telling the time' works through narrative, memory, sound, performance, image and poetics, providing a matrix through which the past is continuously brought to life for performers and audience alike. The paper is in three parts. The first sets the scene, exploring how three, kin-related Kyrgyz genres of telling the past - family trees, genealogies, and epic poetry - are interwoven as people tell their life stories. The second part looks in depth at diverse manifestations of the Kyrgyz epic Manas, and the interpenetration of Manas with social life. The third part reveals how different forms of performing and remembering the epic bring the past to life through the act of performance.

(Keywords: time, poetics, genealogy, epic, performance, memory)

\section{Part 1}

"In the memories of the old men lie the events of the relatively distant past" (Abramzon 1971).

\section{Family time - jeti ata and sanjyra}

'Sen kim balasynby? Whose child are you? Who is your father? Who is your father's father? Who are your jeti ata, your seven fathers? What is your uru'u? Your chong 
uru?' Gulsayra is asking little Ali Beg, aged two and a half, about his relatives. And he is answering, his little voice piping out. This is fun, a game, but also not a game, played while we walk along the road. While Gulsayra is questioning him she is also instilling in him a knowledge of his relatives, his place in the family, clan and local kinship system. This is not something every Kyrgyz child experiences nowadays, although most people when I was first in the field (1990) were proud to tell their jeti $a t a$, their seven ancestors in the male line.

This paper begins its study of Kyrgyz time-telling through everyday personal tellings, kin and genealogical tellings, with details of family history, developing through these to oral histories and epic poetry on a grand scale. Nevertheless, in the beginning, telling the time Kyrgyz-style frequently starts with telling one's jeti ata. There is a long-standing Kyrgyz joke about how any two Kyrgyz people in a room, meeting for the first time, will soon work out how they are related, tracing relations through recounting jeti ata, activated from informal conversations.

Aygul, another friend, felt ashamed because as a single parent, when her son was asked about his jeti ata by family guests, as he would be, he could not tell the answers. Not to be able to recount his seven fathers meant he could not tell within which lineage he could marry, could not tell his children about their forefathers, and thus could not become (in the eyes of some) the head of a family. Such a person could have been described as 'an orphan beaten by God', kuday urgan jetesiz, in the past, having the status of a servant or a wanderer with no place (Hardenburg 2012:274). 
A more formalized way of telling one's family time is recounting sanjyra, Kyrgyz genealogies through the male line. Sanjyra are conventionally oral, although these days sanjyrachy, interested genealogy collectors and esteemed male elders who make it their business to know and tell such accounts, may write them down in handwritten note books and draw on printed texts for authority (Reynolds 2012:77; Hardenberg 2012). Local scholars may also publish them in pamphlets or local history books, and extensive versions were published in Soviet academic texts (revealing a Soviet academic passion for exploring Kyrgyz ethnogenesis which almost matched Kyrgyz interest in their own descent ${ }^{i}$ ). Whether spoken, written down or published, however, these accounts are frequently re-narrated and reworked, as tellers discuss them, and borrow from complementary versions. And although they recount vast networks of men related by descent, different emphases of relatedness are prioritized, according to how a person or family needs to claim status or allegiance in the present through past connections. Thus, they can be, as Halbwachs describes 'lived histories', referring to the past on the basis of present experience (1985: 55). At the same time, however, they are not just histories from below either, since they contain 'great or esteemed people, and often their heroic acts against enemies' from the past (Hardenberg 2012: 269). Women are also co-opted in as wives, mothers, grandmothers, and may be cited to claim links to a woman's male ancestors, most notably seen in the role of Bugu enye, Deer Mother, a sacred ancestor of many significant Kyrgyz forbears. Women also play a significant role in maintaining these family connections through simply retelling them to their children, as Gulsayra did, and also through their womanly work in hosting, from making chai at small men's gatherings to preparing feasts at life cycle events (Reynolds 2012). 
Thus, Kyrgyz genealogies, whether formal or informally told, are not overarching, neutrally obtained charts, starting from one male ancestor and working forwards towards the present, although it may sometimes seem so from the way they are described. They are autopoeitic, 'systems which generate their own conditions of existence' (Gow 1997:1), grounded in daily life, growing outwards from a community, prioritizing its significant ancestors, their deeds and locales from the perspective of people in the present, thus entwining historical relationships with a community's hopes for the future. Different relationships (such as patriliny, affinity, maternal affiliation) may be highlighted selectively to claim relations with a valued ancestor for political, economic or social status reasons (ibid; Jacquesson and BellerHann 2012). And all these connections are told, retold, and reworked in the telling, according to people, events and place.

Recounting a person's jeti ata or sanjyra, family trees through the male line, are ways of telling the time and telling the past in Kyrgyzstan. They are also manifestations of conceiving and articulating historical processes through kinship (see Toren 2018). And time is literally told out loud. These ways of telling the past link to experience, to family and to intergenerational relationships, whether communicated by walking along the road having fun with one's mum while being drilled in ancestral ties; by feeling social discomfort at a family gathering; or by paying particular attention to detail in finding genealogical connections. This is 'time-as-experienced' as Henri Bergson describes (1913), or as Merleau-Ponty describes, our 'human situation in flow'. In this paper, I argue that through the interweaving of such forms of 'telling the time', people express and experience the life within their pasts, their histories, - and so enable the past to come alive. 


\section{From genealogy to oral history}

Central Asian epic poems are altogether more all-encompassing than sanjyra, telling the 'whole' history and origins of particular Central Asian peoples, although they too reflect a similar vitality and historicity, a particular approach to history (see Hirsch and Stewart 2005: 261-3). These days, to the unacquainted European outsider, epic poems may be imagined as classical or 'fixed', written in archaic language texts such as Gilgamesh or the Mahabarata. These ancient histories may have developed through orality, but are now mainly read in scholarly books, and most often discussed as folklore or ancient history rather than anthropology. Yet I propose that Central Asian epics, such as the Kyrgyz epic Manas, which are still lived and performed, (albeit infrequently now), constitute a uniquely dynamic Central Asian way of historicizing, remembering, and experiencing the past, linked to genealogies, social relationships, and to communicating it from a performative perspective (see Baumann and Briggs 1990). Such performances are context sensitive, bringing different ideologies and experiences into an arena where they can be reflected upon critically and are continuously revised according to new events and audiences. They are on the one hand oral histories, based on real-life historical events, negotiated through an audience, and on the other hand they are also poems and prose, drawn from and taking us to that realm of mythopoeic consciousness that is our source (see Mimica 1988: 8). ${ }^{\text {ii }}$ And they also contain details and information about everyday practices, natural ecology, and ideas of how to live appropriately for the specific group to whom the epic belongs. In all cases, whether genealogies, histories or myths, these tellings are set as much into what Benjamin might describe (in his famous reflection on the Storyteller [1999]) as 'the concentrated pattern of the past', as in historical accuracy, 
and whatever the event, the tellers almost always make the time become present. Through this combination of details of everyday life, historical events and universal themes, along with live performance, epics thus extend into a kind of living distilled history, the subject matter moving well beyond events on which they are based, through deep time into the contemporary, although in epic what is myth and what is history is never spelt out.

The antiquity of Central Asian epics is not in question, recorded in historical accounts, such as the Ancient Turk Orkhon inscriptions in South Siberia $\left(6^{\text {th }}-8^{\text {th }} C\right.$ AD), which describe events of the time with similar stylistic features and patterns to contemporary epics. Travellers' tales, such as those by Al-Kashgari ${ }^{\mathrm{iii}}$, have documented similar poems in the region from at least 1000 years ago (Winner 1953:55-8). The age of Central Asian epics is also reflected in their degree of development, since regional groups share episodes or characters of epics, reflecting historical ties from long ago.

In Central Asia, almost all Turkic speaking peoples had epics - Kyrgyz, Kazakhs, Turkmen, Uzbeks, Uyghur, Tatars, Bulgar Turks, Karakalpaks, and even Farsi speakers such as Tajiks have, or had, them. Some groups have several epics, some groups share episodes in common, some characters feature in different episodes of other groups' epics. This fluid and hybrid formation suggests, in similar vein to sanjyra, a dynamic process, whereby certain Central Asian epics, and alongside them, historical events, were shared by groups which, while distinct today, are united by past allegiances and relationships, reflecting a broad and interlinked palette of cultural experience. Epics are thus never isolated stories, but parts of other narratives 
constituting the course of life (se also Benjamin 1936/1999). But however interlinked, any epic for any one group will also be unique and specific to them. Uzbek and Tajik epics are considered more lyrical, containing love songs, and reference to 'the Beloved', reflecting perhaps a close relationship to Sufi poetry. Kazakh and Uzbek epics are often accompanied by stringed instrument, the qyl kobuz, similarly to the Mongolian horse head fiddle, which was also formerly used in baxsi healings. The Kyrgyz epic Manas is rarely accompanied, a featured argued by oral historians to reflect its 'purer' epic form.

In all cases, however, Central Asian epics are centred on the life and adventures of a batyr, a local hero who usually represents the ideal image of a hero for the people concerned. The Kyrgyz epic hero, Manas, led his people from exile in the Altai Mountains to their motherland in Alai. This is arguably the real-life history of migration of Kyrgyz people from exile back to their homeland 1000 years ago. Manas the man is larger-than-life, has incorruptible honour, is hugely brave, has superhuman strength, and the stories tell of war, and sometimes love. These are all epic elements. Rather like sanjyra, epics are almost always told by men, about men, although in some epics women do have strong roles and may even feature warrior queens, such as the Kyrgyz heroine Saikal.

Finally, epics are never just one thing. They contain within themselves a multitude of other Central Asian musical, historical and poetic forms - folksongs, lullabies, memorial songs, dastan or legends, religious songs and so on. They are most often performed at life-cycle ceremonies, sung at feasts, cultural evenings, or religious events such as pilgrimages, and are the ways of telling the past most suited to these 
events. And alongside broad mythical and historical themes, they also contain condensations of lived, practical experience, from ways to live in the mountain environment, to the kinds of dried food needed on migration, added through many tellings, as different singers incorporate these practices into the epic.

\section{Enstorying the past}

In regard to telling the past, it is difficult to say where genealogies end and Kyrgyz oral epics begin. As Féaux de la Croix recounts, if you ask a Kyrgyz person about their tarykh, their history, they will first direct you to genealogies, linking people to people, and often to their ayil/village/camp or jer/tent place (2016: 145-6). Epics too, often begin with genealogies, positioning the hero in terms of his ancestors. Yet, if people tell you their own life stories, they will often begin by situating them in relation to the Kyrgyz epic Manas, incorporating epic-like elements during the telling. During one visit to Gulnara, the wife of Toktosun, she told me her family story, contextualizing it in relation to Manas, the Kyrgyz epic hero, and then emphasized her husband's family ancestors in genealogical mode, before dealing with her own specific situation.

'Manas,' she began, 'is like the ancestor of the Kyrgyz people... She continued, 'In Ak Terek, (White [ie, Sacred] Poplar, Gulnara's husband's village), the oldest relative is Bo'otugur (the White Poplar having grown at the site where he recovered from battle wounds). He is the one man from whom we (her husband's family) are all descended and the original ancestor of this ayil (village/camp) for at least seven generations. This is known here'. Toktosun, her husband, and relatives are descended from this man. It's their uru'u - seven generations, lineage. 
'Also living here are people from the men Katagan, Alagoz, and O'osoy - four uru'us altogether. Maybe these men were brothers, but probably not. The ancestor for the whole region is Ayak Tar. People all remember back to seven generations - their uru'u. Probably, before 1916, when there was the ürkün(the period of terror, culminating in flight from reprisals for an uprising against Russian settlement, and the mass exodus to China and Tajikistan), only Bo'otugur was in this ayil. The others came after. Before then it was a rich time. There were cows, sheep, camels. Life was like that.' (Fieldnotes:1995)

And then she told me her own family story. Gulnara's father was a bey - a rich man. In 1916, he fled to the Jyrgatal region of Tajikistan. The kulaks/peasant farmers ${ }^{\text {iv }}$, the Russians, came before 1916 and people shot each-other and the rich Kyrgyz fled from them. All the beys who didn't go to Karakol and over to China (which his relatives did) went to that region of Tajikistan. Gulnara's father had one wife who died, a son by her, and then he later married her (Gulnara's) mother.

'That first son also came back from Tajikistan after the ürkün and is close family. Now he lives in Bishkek and is a good man, always giving money when his relatives need it. At that time, if you were a bey, with kele (horned cattle), you might marry several wives.'(ibid)

Gulnara said that men tell their sons the names of their fathers, seven generations back, but often the mothers also do. Everyone does this, at least through their father's line. But some take more interest than others. Toktosun's father, Talai (whose name 
Gulnara as daughter-in-law is not allowed to voice), has learned all about her family history as well as his own; this is quite usual. She said that if you remembered your relatives, you also remembered their family where they lived, and what they did.

Then she added (about herself), that she was married in 1979. She was 21, and he was 26. She was stolen. The wife of Toktosun's brother (his only real one), who lived in Balykchy, used to work in a hair-dressers with her. This woman recommended her to Toktosun. And so Gulnara was stolen in a car and brought to Toktosun's house. She didn't know where she was going. Once she was there, they told her family. Her brother and sister came to see her, but she couldn't back out because it would have been bad for her reputation. Your relatives can't really take you back in this situation, even your father, and her father said, 'Get married!' She was very upset. She cried, shouted, and told everyone off, but in the end accepted, and she was happy.

Thus Gulnara 'tells time'. She tells her married family's story, its ancestry, but this is just a starting point. She begins with the context, setting the story within Kyrgyz epic as a whole, and local views of origin. She tells of Bö'ötügör, his links to Ak Terek (her village) and how he is the main local ancestor. She tells how everyone today is linked to him in a vast web of interconnections through epic-like, but true, events such as war, death and migration, who are the local dignitaries, heroes and men of stature, and what such people should do, all punctuated by local time-marks such as the ürkün and exodus to Tajikistan and China. And she tells of similar events, 'of a striking kind', which affected her own family (see Reisman 1974:111). Finally, she tells the detail of how she fits into this picture and the personal, meaningful events which have affected her and which she wants to share. Thus, we have a life-history 
which is grounded in the ways Kyrgyz stories are told, in terms of narrative form, content and imagery. We begin with ancestors who stand out, the local distinctiveness of the area to which these ancestors are attached, and all are imbued with a kind of moral counsel for how to behave in such situations. There is no clear distinction here between a formal historical account and an oral tradition, between individual and collective memory, nor between genealogy and epic tale. When Kyrgyz people talk of the past, this integrated quality often shines through, as they draw on epic elements, characterization and morality in telling their life- and family-stories.

\section{Part 2}

\section{Manas - the Kyrgyz epic}

For my Kyrgyz friends, of all the Central Asian musical and poetic forms, it is Manas which stands out today as the most profound living epic. Thus, people say that Manas is the 'most developed', 'most original', 'authentic' and possibly the 'longest living epic in the world', still performed today. It takes a day and a night to sing, so people say (Musayev 1994). While I heard Manas sung in tents, small village 'houses of culture' and grander staged performances, I also experienced the story as simply told by my friends on several occasions, and it is this ubiquity, Manas' permeation into all aspects of life, and telling in many ways, which reveals and allows the living nature of the Manas epic to continue to re-emerge and remain a vital feature of Kyrgyz timetelling.

'Ilgeri, ilgeri, once upon a time, once upon a time,' my host told me, 'there was a khan Jakyp. Jakyp was Manas’s father. He had many animals, many herds, but he had no children. And he was old. His wife Chiyirdi was 50. He 
was so worried that he had so much land and so many animals that, thinking of his family line, he said 'Who will be instead of me when I have died?'... One day he went into his boz üy, his tent and slept, and he had a dream. It showed his son who would become head over all the Kyrgyz people and be khan...

'The bubu bakshy, midwife, helped Chiyirdi bear her son. The baby was huge. His mother was in labour for three days. Finally he fought his way out, clutching a clot of blood in his hands as big as the liver of the sheep...' He was a terrible, but fearlessly brave child, cutting down sacred trees, scaring old men, drinking bucketfuls of red arak vodka and so on.

'By 12, Manas could stand up against anyone, he was very tall and strong like a batyr, hero, or di'ir, giant. The Kitai and Kalmyks decided to kill him because he would become a threat to them, but no one could beat him. $\mathrm{He}$ formed a group of 40 followers, his kyrk choro, clever-minded khans of the Kyrgyz', so my friend told me, 'such as Bakai and Koshoy. On the advice of old Koshoy, he led the Kyrgyz back to Alai, their motherland, which involved many struggles and battles...Almambet was another clever assistant'...

'Manas was married to Kanikey, a Tajik. There were many, many more battles. In the final battle Manas was betrayed and killed by Kongurbey, the son of Alooke, a Kitai. These are the main facts,' said my friend.

Then he added, 'In Manas you can see how to bring up children, and how to 
care for nature, and old people, and how to live with neighbours and foreigners...' (Fieldnotes 1995)

While often told as above, between people, there are also more formal ways to tell Manas and more formal kinds of tellers. The classic performance is very focused, delivered by one person, the manaschy or singer, usually seated cross-legged, halfsinging, half-telling, accompanied by bodily movements and gestures, but not, until recently (as recorded by Smithsonian Folkways), by instrumentation. There are traditionally special conditions for how and when Manas can be sung: the Seven Sisters (stars - Pleiades) must be in the sky, the poet must not stumble, and so on (Dor 1975:1986). (To my knowledge, many of these conditions are rarely followed today.) The performance itself can be reputedly magical - legend tells that when the $19^{\text {th }}$ century manaschy Keldibek Baribozov began to sing, herdsmen could come to his performances without fear because the cattle would go home by themselves. His songs could cure the sick, problems with childbirth and even infertility (Hatto 1970).

A different kind of formality developed during the Soviet era, when all the episodes of the Kyrgyz Manas epic were pulled together as a whole, and the epos was consolidated and canonised as a cultural form par excellence, as a part of Kyrgyz national heritage, creating one long, defined, self-contained epic (Musayev 1994). Cultural troupes and ensembles performed it in theatres and houses of culture, and the most famous versions, sung by renown $20^{\text {th }}$ century manachys as Sayakbey Karaleyev, and Sagimbey Orusbakov were recorded and published. These singers themselves were memorialised in statues in towns and city squares, many still 
standing today. People even make pilgrimage to the shrines of great epic singers (see Debuisson and Genina for similar Kazakh pilgrimages, 2011:475).

\section{Figure 1 Statue of Sayakbey Karaleyev, Bishkek, 1996}

Kyrgyz poets and storytellers in general are called yrchy (singer, poet) or akyn (storyteller). Like the recently 'complete' Manas epic, the manaschy or Manas singer, is arguably a comparatively new (approximately 100 years) development, although it reflects long-standing regional practices around epic singing. To become a manaschy is often described as similar to becoming a shaman (Chadwick and Zhirmunsky 1969; Centlivres 1971). A young person becomes ill, they take to their bed, sometimes for weeks, and during the illness, one of Manas's 40 choros, companions, comes to him. When he recovers, sometimes he can sing Manas from start to finish. To sing Manas is a gift, a birth skill, and it must be used wisely. At the same time, in my field experience, young children who showed an interest in Manas were encouraged by their mums to sing different episodes, to pay attention to Manas's different qualities in their behavior, to learn sections of verse. The young singer may then be taken to a professional manaschy and, if accepted, undergoes an apprenticeship with this adult singer. Not everyone can take this on, a manaschy needs a 'strong spirit'.

With its focus on past greatness, and its condensation of genealogy, historical battles, political power and heroic behavior, epic poetry can also act as a rallying call, as was the case following the expansion of and conquest by the Russian Empire, and the subsequent creation of the Kyrgyz Republic as a nation with boundaries and citizenship by the USSR. As both a very coherent narrative of origins of a people and 
a poetic form which has the power to move them, this form of telling the past can both unify and politicize people, invoking their 'continued existence and historical vicissitudes' (see also Harris on the Andes, 1995: 205). Because of this, epic singing was at times suppressed, and singers were even imprisoned in the region during both Russian conquest and the Soviet era, while Kazakh bards formed a resistance movement in the late years of the Russian Empire (Akiner 1995).

In Kyrgyzstan, as a feature of the emergent political ethos following Kyrgyz independence in 1991, the first Kyrgyz president, Askar Akaev, cited Manas as the only ideology that the fledgling Kyrgyz nation needed for its place in its new globalized role. This he said at the inauguration of the Manas 1000 festival at Talas in 1996, which was held at Manas's newly proclaimed burial site. The Manas 1000 festival itself acted to situate the new Kyrgyz republic within its epic-historical context and was also the occasion for the first Kyrgyz ordo, - the first mass clan gathering, since the early $20^{\text {th }}$ century ordo of Shabdan Khan. Such gatherings were banned under Soviet rule. On this occasion, rather than being the focus for performance by epic singers, Manas was performed as a theatrical spectacular with a cast of thousands and an invited international audience to witness this oral performance of nationhood. This adaptive nature of epic performance in regard to political power is discussed in Prior's work on $19^{\text {th }}$ and $20^{\text {th }} C$ Kyrgyz poetry (2012).

\section{Figure 2 Manas festival perfomance}

Epic is, however, much more than political discourse. To focus on the purely political would be to ignore the salience of Manas for all the other realms of experience it 
connects, from genealogical relatedness to life stories, from local ecology to universal themes. These connected realms of experience are the focus of this essay and today are given expression in multiple forms. Along with orally recounted versions of Manas, there are transcribed recorded Russian and Soviet texts with printed illustrations. A classic depiction, much imitated, is by Theodore Herzen, a German woodcut artist of the Soviet-era (Prior 1995). Alongside the brooding central image of the hero, around each central image are featured powerful sacred animals, invoking Manas's connection with the mountain landscape and all its sacred, enspirited aspects, eagles, dragons and even tigers. Manas also features in all manner of public art, most recently seen in a new statue which has become the latest image to replaced Lenin in the main square in the Kyrgyz capital, Bishkek.

\section{Figure 3 Manas statue Bishkek, 2016}

And alongside this, Manas' actions are recounted in daily mealtime conversations; in allegorical comments made to children aiming to inspire a positive moral tone or behavioral response ("Manas Ata - father Manas - would not do that"...); discussed on TV chat shows; and in explanations to foreigners such as myself, who did not grow up with him as an ancestor. He is visually depicted on Coca Cola billboards in cities, featuring new forms of consumption; in children's drawings of Kyrgyz heroes (Chochunbaeva 1996); and in English language newspapers. Foreign scholars such as Theodor Levin write about him, feature him on websites, (see http://www.musicofcentralasia.org/Tracks/Chapter/4 and Levin et al 2016). Thus, to paraphrase Erlman, despite the fact that Manas is a story to be told, today one has to 
give the eye place alongside the ear when considering the epic and its hero (2004).

The epic is part of people's 'lived' experience in multiple, interwoven ways.

Figure 4 Manas 1000 Billboard, Bishkek, 1995.

\section{Part 3}

\section{Bridging time and experience/Bringing the story alive}

When my Kyrgyz friends told me stories about the past, I was always struck by how 'present' these accounts were. As if the telling made these events (historic flights to Tajikistan, earthquakes, or Manas's meetings with his followers) seem as if they had happened just yesterday, as if the teller had been present, and this presence also made the event present for me.

As illustration, my host in Geng Su'u jailo'o once recounted a battle between Kalmyks and Kyrgyz in the valley nearby, describing which group was positioned where, who hid behind the rocks, who ambushed who, and so on. It took me some time to grasp that this was not a story of several months or even years ago, but possibly several centuries, such was the immediacy of the account. It was as if the many lifetimes of their telling from person to person gave these stories the quality that brought them alive.

For Kyrgyz time-telling, I suggest the effect of the mutual constitution of epic between teller and audience, similarly work to make them become present, alive when told. In this regard, I draw again on Benjamin's Storyteller, where 'The storyteller takes what he tells from experience... and he makes it the experience of those who are 
listening to his tale' (1999: 87). My interest in this kind of time-telling, is clearly related to what we call 'history', but also to the greater human story, less concerned with time as accuracy, timeline or 'information' (see Hirsch and Stewart, 2005), but with time as duration, 'time-as-experienced' (Bergson 1913), the 'human perception of being in time' (Hirsch and Stewart, 2005: 263). To witness a performance of Manas is to experience the past, present and future mutually implicated, the patterned living history and myth of the Kyrgyz people.

To summarize my argument, Kyrgyz epic moves between telling and experience through, on the one hand, the condensations of temporal experiences linked to family connectedness, historic facts, the learned wisdom and the universal themes contained. These I have discussed above. On the other hand, it achieves this through the dynamic between the poetic and performative aspects of the telling. The very act of performing epics affects their recreation and renewal, the power of the spoken word and the resonance of verbal and visual imagery communicated through performance having implications for their reception and experience, and vice versa. Memory here is also key, bridging performance and experience, the act of lived remembering affecting performer and audience in multiple ways. These I will address below.

\section{Learning to tell the time - remembering and recreating epics}

While this paper is not directly about memory, different nuances of 'memory' do provide food for thought and are relevant to time and its telling. There is the individual intentional act of the singer to learn, memorize and then re-member the poem during performance. This could be bracketed as 'learning' or skill, intentional human development through experience and effort. There are also individual 
participant experiences of life and memories of time-past in people's lives, including experiences of performances of Manas, held in people's minds as memories that are personal to each individual hearing or telling of the epic. In relation to time, this aspect of memory parallels Bergson's inner durée, the memory of qualitative temporal rhythms of 'subjective consciousness' (see Munn 1992: 95). And there is the sense of shared memory, held by people who share and experience a group's past during and before the time when their own personal memories begin - memory's collective aspects, between and with people, (the 'com' aspect of com-memoration), and its improvised, re-creative performed and repeated aspects (the 're' aspect of remembering) (see Halbwachs 1980 [1950]).

However, what we may categorize as 'memory' can also bridge the everyday and the sacred. Com-memorating Kyrgyz ancestors, arbak, entails more than remembering genealogies or recalling them in epics, since ancestors have a sacred aspect and can become literally present on some occasions. People conduct memorial ceremonies for ancestors, cook with hot fat to invite them to feasts so that they will come and feed upon the aroma, ensuring their spirits and their memories are nourished (Bunn 2010). Ancestral tombs are sacred in the same way as springs or tree groves are, all are called 'mazar,' a borrowed Arabic term for 'sacred place'. All are nodded to when passed and visited to honour the dead. The actions of heroic ancestors can even result in such sites being created, as mentioned above in relation to Bo'otugur. Even learning, or memorizing, Manas has sacred aspects, requiring great strength and a strong spirit for the manaschy. What is performed is not simply learned or re-membered, but rather, as discussed above, comes to the singer in a dream (see above), and is thus a way of allowing the past to speak through the singer, where Manas becomes embodied in the 
manaschy, grounded in his affinities with the characters of the epic, communicating the past directly to the audience. In this aspect, manachys "are mediums for the knowledge that comes from that world, rather than being themselves the repositories of knowledge" (Harris: 116). Here, the past is accessed, not reassembled, and those "criteria constitutive of standard Western history fall by the wayside" (Hirsch and Stewart 2005, 266).

The practicalities of learning, remembering and performing oral epics was famously linked to their poetic form in Walter Ong's Orality and Literacy. Ong's initial analysis was based on the work of folklore researchers Parry and Lord (Lord 1960). They proposed that many classical texts, such as Homer's Iliad and Odyssey, the Rig $V e d a$, and even the Bible, must have arisen as oral forms, since they had multiple characteristics more resonant of them having been originally told and retold, rather than composed by an individual and then written down. Most significantly, they found patterns in oral epic, such as the use of repeated themes and formulae, which could be reprised throughout the poem in slightly different words. These repetitive themes and formulae, they argued, enabled the epic to be memorized and reproduced with greater ease, although they also made it very clear that the performance of epic was not so much one of memorization as of improvisation.

How could a poet remember such a long poem verbatim? Despite claims of the purity of memory and exactness of the epic singer (an aspect of his mystique often claimed for Kyrgyz manaschys), you would be unlikely to encounter a Kyrgyz manaschy who would sing exactly the same version of an episode of Manas twice. The whole process is, as Parry and Lord propose, arguably not one of repetition of an exact text, but one 
of rapid improvisation and composition in performance, using the themes, phrases and patterns which arise again and again throughout the epic, often in slightly different forms as the epic is performed. Thus, as Parry and Lord propose, the epic singer is more of a 'composer' within a system of familiar elements, than reproducer of remembered texts, guided by the story and pattern of the epic.

The kinds of themes that appear again and again, not just in Manas, but in many epics across the region, include 'the dream', 'the council', 'the feast', 'the battle', 'the birth', 'the wedding', 'the hero's horse', 'the hero's helper'... Many were referred to in the short version I recounted above. Of course, such themes are undoubtedly memorable, but to see memorization as their main role would be one-dimensional. Such themes are powerful elements of any good story, including the Manas story my friend told me. Furthermore, many are key life-cycle events, or personal and group 'time-marks', and as such, they are also part of what makes life interesting, engaging and worth talking about. They command direct attention and connect with the audience as well as assisting the performer.

What Parry and Lord describe as formulae are more detailed than these broad themes, referring to particular ways of recounting specific characters or events which allow for a repeated series of descriptions each time they are begun. For example, if describing one of Manas's 40 companions, the singer will usually then describe them one after the other in turn, each time mentioning their names, their unique qualities, or reciting their linked yet contrasting skills and capabilities:

'Kaman and Joipur, even in darkness, never lose the wolf track;

Tursun and Tailak, even at night, never lose the fox track' (Hatto 1970:17). 
Or there might be striking contrasts, always repeated:

'If you kill me on the mountain, put me in the ravine, my friend, If you kill me in the ravine, put me on the mountain, my friend.'

Dor 1986:98.

Ong, in particular, interprets such features of epics, including these themes, formulae, and their repeated vivid imagery and larger-than-life characters, as purely mnemonic devices which, he says, are essential if such long poems are to be remembered by the singer. Without writing, suggests Ong, there is nothing outside of the thinker to help him or her to produce the same line of thought again. The only solution, he says, is to 'Think memorable thoughts' (1982:34).

It is here that the relationship between memory, poetics and performance needs to be given more attention, perhaps in parallel to that between memory and the sacred, and so does the relationship between singer and audience. The different themes and episodes, so very evident in Manas, are both larger than life and the stuff that stories made of, of interest to both individuals and their groups as striking events in their life histories and the mythic rhythm of their pasts. The contrasting and repetitive way of recounting characters and events is not just memorable, but is rhythmic, rhyming and has a contrapuntal quality, a musicality, and the images are very powerful. These poetic and dramatic phrasings form important and impressive elements of a narrative, creating images which captivate the audience. Here it is possible to expand on Gell's notion of 'abduction' or 'captivation' (1988). At the same time as such patterns and imagery may assist the singer to remember, the audience is quite simply enchanted by 
the imagery, musicality and poetic force. Thus, through the poetics of performance, the manaschy bridges time and experience, communicating and sharing the past with the audience, drawing people inside their own histories, to make them immediate and compelling. This synthesizes both personal and social memory, which through different collective experiences and tellings of the past, can anyway never be entirely separated.

Here we are also encountering the kind of process that Hallam and Ingold describe as 'cultural improvisation' (2007), where the epic is recreated, renewing meaning and significance each occasion it is performed. Thus, themes and patterns act as matrices around which the poem is spun, rather than memorized segments out of which it is constructed, in similar vein to the way that Kyrgyz traditional felt textiles (Bunn 2010) are built up from different 'traditional' patterns, yet no two are ever the same, giving them a continued dynamic and vital quality. Such social and cultural practices are never simply reproductions of old forms, but are rather created anew between people in an improvised way each time they are practiced. They succeed because they are inherently meaningful, because their striking form touches people's aesthetics, their memories, links to ancestors and enables them to come alive for participants, and because they are recreated in a performative action, rather than simply memorized and reproduced.

Finally, the repetition and imagery of Kyrgyz epic has a further role for audience as well as for singer. If a story is written down, the reader has the luxury of being able to go back over the words, to savour them and revisit any significant parts. But, as Ong argues, in oral epic, the audience has no tangible written prop to refer back to. 
Repetition arguably fulfills this role, enabling the audience to re-savour the imagery. One field companion likened repetition in Manas to an animated film, developing a sequence of slightly changing images to create movement. This, she said, is one way that Manas comes alive for the audience.

\section{The Poetics of Manas}

If epic poetry is to be considered as primarily a form of oral performance, rather than a challenge to memory, then what is the significance of sound and the spoken word? After all, Manas is first and foremost oral and aural, composed and communicated primarily through vocalization in performance to be experienced through hearing. It requires the companionship of teller and listener and is dependent on the human capacity for telling a story in action and understanding through hearing sound and words.

Two important features give insight to the role of sound in Kyrgyz poetics. Firstly, there is no separation in Kyrgyz language between poetry and song. The Kyrgyz word $y r$ means 'song' or 'poetry', and there are many forms of $y r$. To hear a manaschy 'sing' is therefore to experience something which transcends the division between the spoken and the sung word.

Secondly, a different Kyrgyz instrumental musical genre, kü' ü suggests a contrasting emphasis in the relationship between sound and narrative in performance to the one European listeners may usually hold. Kü'ü means 'frame of mind' or 'mood', but it is also the name of a genre of music played on the Kyrgyz komuz, or three-stringed lute. In this genre (described by Kyrgyz musicologist Kaybylda u'uly 2000) a story, event 
or legend is recounted literally through the power of melody, with no words. The musician might give a brief account of events before playing, using gesture to reinforce the narrative, but the story is told through the melody and force of performance, the sound depicting the range of emotions, mood and events arising in the narrative.

These two examples highlight a discussion raised by Ingold on the relation between speech, music and song. Ingold argues that, in the Western 'classical' tradition, we consider the meaning of spoken words to lie "behind the sounds" rather than "within the sounds of speech themselves", so that "whereas the essence of music is sound, language is mute" (2007: 6-7). And in this view, in Kyrgyz epic it would follow that its musicality is a "mere embellishment or accompaniment". In contrast, Ingold argues that we can only think of poetic or sung sound like this because we have become used to thinking of the written image when we think of the spoken word.

That sound without words can convey mood, and even narrative, in Kyrgyz musical performance is highly relevant to the performance of epic and to the non-verbal contribution of sound in the telling of epics. This significance of sound in Kyrgyz poetics reminds us that sound can be affective in an intersubjective way, through forms of resonance. This is not just due to the meanings of words but to the quality of the sound itself. As Stoller describes for Songhay musicians and praise poets, sound has power, it can travel through a person, changing them. For Songhay, the violin may be the voice of the spirits, while the drum, he says, evokes the power of the past (101-3). The potential of a parallel sonic quality for Kyrgyz epic can be explored through three aspects of their poetics: the agglutinative, rhyming quality of spoken 
Kyrgyz; the iconicity or bodily resonance of spoken Kyrgyz; and the use of onomatopoeia or environmental resonance in the sound of the song as sung by the manaschy.

Kyrgyz, like other Turkic languages such as Turkish, uses vowel harmonies and rhyming suffixes added to the ends of words to convey additional nuances of meaning such as plurals, cases, even occupation. These suffixes have a range of phonic options in order to rhyme with the initial sounding of the main word stem. For example, while the plural of adam (man) is adamdar, the plural of kitep (book) is kitepter; the material jygatch (wood) leads to the occupation jygatchy (wood-worker), while the environment tokoy (forest) leads to the occupation tokoychu (forester), and so on. Thus Kyrgyz language itself has a harmonic rhyming and rhythmic aspect which gives it a poetic force, even in everyday speech. The poetic language of Manas is a special form of spoken Kyrgyz, to a degree comparable to Chaucerian English. Still harmonic, it uses a different word order, a specialised grammar, which is rhythmic, memorable, one that the singer can make his own. This perhaps gives it the kind of poetic and magical quality that Tambiah describes in his Magical Sounds of Words (1968), where the 'foreign' sound of the language of prayer give the utterance a more powerful force, enhancing its impact further.

Linked to this is a second form of sonic resonance in the Kyrgyz language, its iconicity. Linguistic iconicity is discussed by Alfred Gell in relation to the Umeda language of Papua New Guinea (1979; see also van Leeuwen 1999). Umeda language, Gell argues, has a poetic force because the meaning of words resonates with the bodily process of making their sounds. This, he proposes, is because how the 
mouth makes the sound and the body experiences it merge into one sensation and meaning, a phenomenon he calls 'phonological iconism'v. In his example, Gell illustrates this through the sensuality of certain Umeda words and their corresponding meanings linked to food, eating and sex. In Kyrgyz, too, there is arguably a degree of what Gell calls 'primary phonological iconism'. As a simple illustration, kichi, or kichiniki, meaning 'small', or 'very small', use a small, almost closed, tight front mouth in articulation, while $a c h$, meaning 'hungry' or 'open', uses a wide-open back mouth to make the sound, so that the meaning of the word resonates bodily with the process of its sound-making. Gell proposes that some languages are more iconic than others, with more poetic resonance. He cites Umeda and Gaelic, for example. I would propose also Kyrgyz, Kazakh and other Turkic languages have similar iconism, where there is a poetic resonance between meaning and sound-making.

A third form of sonic resonance in Manas is encountered through onomatopoeia. This has parallels to the way that Stephen Feld describes the use of environmental phenomena and their resonance to inspire both specific sounds and compositional structure in Kaluli poetics in Papua New Guinea (1982; 1984). For Kaluli, this reflects the importance of the rainforest environment in both local beliefs, and the way it structures people's everyday auditory experiences. Although very differently, Kyrgyz herders have a profound attachment for their local landscape that also impacts upon their poetics. This is embedded in the needs and knowledge required to work with animals, both herding and hunting, and for moving, nomadising, in the local mountain-scape. It extends from the lived experience of a herding family in mountain pastures, where people attune themselves to hear the different sounds of raptors, wind, sheep, approaching horses, or wolves, across a wide horizon, to their worldview, 
which is one where people, land and its non-human inhabitants exist in a relationship of mutuality. In more rural Kyrgyz areas at least, this foregrounds a very specific Kyrgyz relationship with the environment, of balance, in which human destinies and the destinies of other inhabitants and forces in the landscape, whether animals, weather or spirits of place, are closely interwoven (Bunn 2011). This extension of the importance of nature, from the practicalities of life, through to the sacred in the environment form an aspect of Kyrgyz aesthetics, and is also encountered in Manas, where there is also an expectation that Kyrgyz manaschy will convey the sound of the environment, of mountains, weather and animals through their voice, just as the komuz can convey mood through melody (Musayev 1994; Wasilewska). This is heard through the nuances of tone made by the singer in different parts of the epic, mirroring the sound of weather, the snow leopard, and so on.

Thus, there is an understanding that narrative can be conveyed through musicality in Kyrgyz musical genres; a poetic, embodied resonance in the very sound of the Kyrgyz language; an emphasis on resonance with sounds of the natural environment in Kyrgyz epic singing, all of which point to how conveying meaning through sound alone forms a significant element of Kyrgyz time-telling.

\section{Stories that move}

To illustrate the power of the spoken word, my host once told me the following story about how the valley at Geng Su'u, in the Kyrgyz Ala To'o where his family lived, came into being. He set the scene beginning with Manas, showing how the power of words may affect not just people, but the land around, acting as a kind of force of creation. 
'Manas is like an assistant. He's a special person, like a moldo, or a mullah an extra-sense ${ }^{v i}$. When an extra-sense begins to speak about somebody for a long time, sometimes during the speaking, it may begin to rain, the wind will begin to blow strongly. An example of this is a story about here. Before, (long ago) there was no valley (here) - one person began to tell a tale about God's wishes, the future. Then hard rain began, and there was a flood. Maybe after this there was a valley. The weather and nature were changed. Stones fell from the tops of mountains and broke, a strong wind began. Maybe many people drowned. Some of the strongest found a way to live, and to leave the dangerous places. Such a situation will happen maybe one time in a century.' (Fieldnotes 1995)

This story reveals the power attached to the spoken word in Kyrgyz, both through sound and meaning. This is encountered not just in poetics, but in daily speech. Kyrgyz do not always give things their true names in case bad luck follows. A spider, for example, will be a 'guest'. A woman will never say her father-in-law's name. A name can even avert destiny. To call a girl Burul, 'Turn around', would be to ask for a son next time, for example. The blessing you give to a newly born child will be carefully worded, in case you praise it too much and God wants it back. Manas was sometimes called 'Big Stupid' to deflect knowledge of his special powers, and to avert his enemies' attention.

If names can impact upon a person's destiny, and if an extra-sense can change the landscape through the spoken word, an epic singer can draw on a vocabulary of words 
and images to make the past present for their audience. And, while sound in Kyrgyz poetics resonates with a Kyrgyz environmental aesthetic, this aesthetic works through meaningful speech too.

This synthesis of the power of spoken words with the Kyrgyz environmental aesthetic allows images to emerge which are evocative and revelatory. This is illustrated through the association of heroes with sacred animals and forces of nature in Manas. For example, Manas' closest companion, Almambet, is described as follows:

'Kite of the hills, Almambet,

Grey-maned he-wolf, Almambet ...'

Who when he fought with Chubak ...

'... from his mouth smoke poured out,

from his eyes, flames leapt crackling.

Faster and faster he skipped

and the weather changed with a roar ...

A cloud was ripped open in the sky ...

Against the heavens, all aflame,

Almambet loomed like a dragon ...' (Dor 1986: 18).

This resonant, repetitive imagery, evoking bodily attunement and human relations with non-human element of the environment, contributes significantly to the force and power of Kyrgyz poetics. The verbal imagery both connects people to the local geography and environment in a very visceral way, and yet also mirrors my Kyrgyz companions' understandings of their relationship with animals and other non-humans on a mythic level ${ }^{\mathrm{vii}}$. 
Thus, if the narrative of the epic evokes temporal events which resonate with life's occurrences, its poetic devices and aesthetics resonate with the natural environment and its inhabitants in terms of sound and meaning. In Manas, these devices include metaphors, contrasts, and use of parallel or reversed imagery, which link humans with hunting practices, sacred animals, and non-human elements such as the weather. Similar forms were again foreshadowed as long ago as in passages of writing on the Orkhon inscriptions (Winner 1953:58).

What these features of Kyrgyz poetics reveal is that all these powerful images, evoked through narrative, words and sound, and situated so forcefully in the local geographical, historical and enspirited environment, work to bring the audience inside history. Rather like Hirshkind's description of the body becoming permeated with emotion through listening to cassette recordings of the Koran in Egypt, creating a kind of moral kinaesthetic experience (2001), so, I'd suggest, listening to a live performance of Manas permeates the Kyrgyz audience with their past, giving past memories and relationships an almost lived immediacy. This it does through the diverse narrative and sonic features of the epic in performance. This gives a vitality to the emergent and auto-poetic process of binding lived experience, story and history into one experience over time, creating a kind of ultimate, resonant Kyrgyzness, which is both environmentally and temporally situated.

\section{Conclusion: Telling the time}

I am not suggesting that my Kyrgyz companions somehow experienced time differently from other people. There is, as Gell remarked, commonsensically, 'no 
fairyland where people experience time in a way that is markedly unlike the way which we do ourselves, where there is no past, present or future' (1992:315-17). Nevertheless, I am concerned with how telling the past may call up a special kind of attention and engagement with it, through incorporating its telling into experience. As Bauman argues, narrated events and narrative events cannot be separated in oral performances (1982: 5), and neither can be separated from the milieu in which they are generated.

Hirsch and Stewart question whether "a dream, a song, a dramatic performance... or the perception of the landscape [can be] usefully classified as history?" (2005: 266). And they conclude "yes", because through these forms people are contemplating the past and producing knowledge about it. Yet these forms are themselves media, matrices through which the past is not just contemplated, but experienced. The child recounting his jeti ata, the sanjyrachy, the woman telling her life-story, the epic singer, are not just giving 'information', this is not simply a uni-linear history, because these forms are outside what we consider to be "all real historical categories", they are told to be heard, as stories which make up bigger stories (Benjamin, 1999: 88). Epic, in particular, through being told, incorporates these other forms, and is the soup through which history emerges, where everyday histories connect past to present, hence the immediacy of the past. Epic thus forms the "great simple outlines" that Benjamin describes (1999: 83), providing the greater way of thinking about and incorporating persons into a story of the past.

The Kyrgyz context for telling the past is poetic, where sound and the spoken word are important elements, and so is the environment in which people live, and so are 
those who came before. If this is history, it is not the kind of history where "events are explained by placement in chronological relation to other events" where change is accounted for by 'facts' or ‘information' (Hirsch and Stewart 2005: 265-7). Rather, the dynamics of change are part of the process. The epic singer may be a history teller, but unlike the historian he is not bound to explain but can reveal these happenings as "patterns of the course of the world" connected to other stories (Benjamin 1999: 95). Such rich evocation expressly sets out to reveal rather than explain, even after thousands of years capable of arousing astonishment and some thoughtfulness (ibid: 90-95), providing some profound insights to the relationship between experience and story, between human action in time and causality. Epic accounts have a mythical quality in that they condense the accounts of people from many times, and are capable of releasing the strength of the story even after a long time. Thus, they contain intelligence, counsel, imbued with the experience of distant travel or the temporal condensation of tradition. This gives them wisdom.

If epic can evoke the pattern of change, it also incorporates life as it goes on, through Russian conquest, Soviet-era to independence, the formation of the nation-state and the advent of global capitalism. As the landscape of Manas changes, so does the soundscape and the sound of Manas sung, from its more local raw, animistic sounds, to a more formal monumental Soviet sound, to its more recent New Age globalized style. And so does the way it is learned and communicated.

There is a very strong possibility, as Kyrgyz film-maker Melis Ubukeyev once commented (pers), that transcribing epic to text may have signalled its demise, in that inscription reputedly freezes orality. Having seen young Ali Beg, my young 
companion from the start of this article, at two and a half years old watch every TV programme and documentary on Manas, and sit with his mum learning it, his own tiny voice becoming like that of a leopard or a lion, even though he had to be bribed with chocolate to sing, I would say however, there is still a strong motivation to learn the epic. But I am also somewhat compelled by a concern (also voiced by Benjamin) for the decreasing social need for story (as opposed to information), for the companionship of stories and for telling time through linking the words, soul, eye and hands of the people (1999: 100), which he suggests are the necessary medium through which the teller reaches through his own life to the lives of others and makes this the experience of those who live now, told between many people, repeated through generations, and always in the company of others.

Acknowledgements This article is based on fieldwork in Bishkek, and in pastures and villages in Issyk-kul, Naryn and Talas regions in Kyrgyzstan between 1990 and 2015. Thanks to all my Kyrgyz friends, hosts and colleagues, most especially dear Damira Sartbayeva, who has advised and given feedback on these words and ideas, and Alpymysh Orozaliev, who gave me much of my insight to Manas.

\section{Bibliography}

Abramzon, S. M.

1971 Kirgizy i ikh Etnogeneticheskiye i Istoriko-kulturnye svyazi (The Kyrgyz and their Ethnogenetic and Historico-cultural links). Leningrad: Nauka.

Akiner, S.

1995 The Formation of Kazakh identity: from Tribe to Nation-State. London: The Royal Institute for International Affairs 
Baumann, R.

1986 Story, Performance and Event: Contextual Studies of Oral Narrative.

Cambridge: Cambridge University Press

Baumann, R. and Briggs, C.I.

1999 Poetics and Performance as Critical Perspectives on Language and Social Life.

In Annual Review of Anthropology, V 19 (1990), 59-88

Benjamin, W.

1999 Illuminations. London: Pimlico

Bergson, $\mathrm{H}$.

1913 Introduction to Metaphysics. London: MacMillan and Co.

Bringhurst, R.

1999 A Story Sharp as a Knife: the Classical Haida Mythtellers and their World.

Toronto: Douglas and McIntyre.

Bunn, S. Nomadic Felts. London: British Museum Press

Bunn, S.

2011 Moving people and the fabric of society. In Central Asian Survey, 30:3

Centlivres, M. and C.

1971 A Muslim Shaman of Afghan Turkestan. In Ethnology, 10, 160-173

Chadwick, N. and Zhirmunsky, V.

1969 Oral Epics of Central Asia. Cambridge: Cambridge University Press

Chochunbayeva, D.

1996 Manas Through the Eyes of Children. Bishkek: Meerim Foundation

Connerton, P. How societies remember

Debuisson, E.M. \& Genina, A. 
2011 Claiming an Ancestral Homeland: Kazakh Pilgrimage and Migration in Inner Asia. Central Asian Survey, 30:3, 469-485

Dor, R .

1975 Contribution à l'Étude des Kirghiz du Pamir Afghan. Paris: Cahiers Turcica.

Dor, R.

1986 Le Chant dans l'orature Kirghize. In Cahiers de Poetique Comparée. No 12.

Dossiers d'Archaeologie 1996 No 212. Paris.

Erlman, V.

2004 Hearing Cultures: Essays on Sound, Listening and Modernity. Oxford: Berg

Feld, S.

1982 Sound and Sentiment. Philadelphia: University of Pennsylvania Press

Feld, S.

1984 Sound Structure as Social Structure. Ethnomusicology 28 (3), 383-409

Finnegan, R.

1977 Oral Poetry : its Nature, Significance and Social Context

Cambridge: Cambridge University Press.

Foley, M.

2013 Life Lessons from Bergson. London: MacMillan

Gell, A

1988 Technology and Magic. In Anthropology Today. V4, no2, pp 6-9

Gell, A.

1979 The Umeda Language Poem. Canberra Anthropology, 2 (1), 44-62

Gell, A.

1992 The Anthropology of Time: Cultural Constructions of Temporal maps and Images. Oxford: Berg 
Gow, P.

1997 O Parentesco como conciencia humana: o caso dos Piro. In Mana, 3 (2): 39-65.

Gulette, D.

2008 A State of Passion: The Use of Ethnogenesis in Kyrgyzstan. In Inner Asia 10:

$261-79$

Halbwachs, M.

1980 [1959] The Collective Memory. New York: Harper and Rowe

Hallam, E. and Ingold, T.

2007 Creativity and Cultural Improvisation. Oxford: Berg

Hardenburg, R.

2012 Collective, Communicative and Cultural Memories : Examples of Local

Historiography from Northern Kyrgyzstan. Central Asian Survey, 31:3, 265-276

Hatto, A.T.

1970 Shamanism and Epic Poetry in Northern Asia. Foundation Day Lecture.

London: School of Oriental and African Studies

Hatto, A. T.

1977 The Memorial Feast for Kökötöy Khan. Oxford: Oxford University Press.

Hatto, A.T.

1990 The Manas of Wilhelm Radlov: Wiesbaden: Otto Harrassowitz

Hirsch, E. \& Stewart, C.

Introduction: Ethnographies of Historicity. In History and Anthropology, V16, No3, pp 261-274.

Hirschkind, C.

2001 The Ethics of Listening: Cassette-Sermon Audition in Contemporary Egypt.

American Ethnologist, (Aug 2001), 623-49) 
Hymes, D.

1974 Ways of Speaking. In Explorations in the ethnography of speaking, by R.

Bauman and J. Sherzer (eds), 433-51. Cambridge: Cambridge University Press

Ingold, T. 2007 Lines. London: Routledge

Kaybylda u'uly, A.

2000 Ku’u Bayany. Bishkek: Kyrgyzstan Jazu'uchlar Soyuz

Jacquesson, S. \& Beller-Hann, I-H.

2012 Introduction. Central Asian Survey, 31:3, 239-249

James, W. \& Mills, D.

2005 The Qualities of Time. Oxford : Berg

Levin, $\mathrm{T}$.

1996 The Hundred Thousand Fools of God. Bloomington: Indiana

University Press

Levin. T., Daukeyeva, S., Köchümkulova, E.

2016 The Music of Central Asia. Bloomington: Indiana University Press

Lord, A.

1960 The Singer of Tales. Cambridge Massachusetts: Harvard

University Press.

Luria A.R.

1976 Cognitive Development: Its Cultural and Social Foundations. M.Cole (ed).

Translated by M Lopez-Morillas and L Solotaroff. Cambridge Massachussetts:

Harvard University Press.

May, W.

1995 Manas Volume 1. Moscow and Bishkek: Kirghiz Branch of International Centre, Traditional Cultures and Environment. 
May, W.

1995 Manas Volume 2. Moscow and Bishkek: Kirghiz Branch of International

Centre, Traditional Cultures and Environment.

Munn, N.

1992 The Cultural Anthropology of Time. In Annual Review of Anthropology, V21, pp93-123

Musayev, S.

1994 The Epos Manas. Bishkek: Sham Press

Ong, W.

1982 Orality and Literacy: the Technologizing of the Word. London: Methuen

Pomme-Clayton, S.

2006 The Whole Brain: Tales Told in Central Asia. 8.15pm, $10^{\text {th }}$ November 2006:

Radio 3

Prior, D.

1995 Manas: the Epic Vision of Theodor Herzen. Bishkek: Far Flung Press

Prior, D.

2012 The Shabdan Baatir Codex. Brill

Reisman, K.

1974 Contrapuntal Conversations in an Antiguan village. In Explorations in the

Ethnography of Speaking, by R. Bauman and J. Sherzer (eds), 110-24. Cambridge:

Cambridge University Press

Reynolds, R.

2012 Locating Persons: an Ethnography of Personhood and Place in rural Kyrgyzstan.

University of Glasgow: Unpublished PhD Thesis

Stoller, P. 
1984 Sound in Songhay Cultural Experience. American Ethnologist 11 (3), 559-70

Tambiah, S. 1968 The Magical Power of Words. In Man, N.S. V3, No 2, pp 175-208

Van Leeuwen, $\mathrm{T}$.

1999 Speech, Music and Sound. London: MacMillan Press.

Wasilewska, E.

1997 The Past and the Present: the Power of Heroic Epics and Oral

Tradition - Manas 1000. In Central Asian Survey, V16 (1), 81-95.

Winner, T.

1953 The Oral Art and Literature of the Kazakhs of Russian

Central Asia. Durham NG: Duke University Press

\footnotetext{
${ }^{\text {i }}$ See, for example, Gulette's A State of Passion for a developed version of this discussion.

${ }^{i i}$ Mimica 1988: 8. See Mimica's notion of mythopoeia, as a 'constitutive cognitive-

emotional framework, and the correlative epistemic activity' which shape a people's

way of 'being in the world'; the source of their 'world view'.

iii $11^{\text {th }} \mathrm{C}$ author of the Compendium of Turkic Languages, he travelled between Kashgar and Baghdad.

${ }^{\text {iv }}$ Russian term for well-off peasant/peasant farmer, often enriched through migration to parts of the Empire, and perceived as class enemies following the Revolution.

v This is in contrast to de Saussure's approach to language, where sound elements have no relation to meaning.

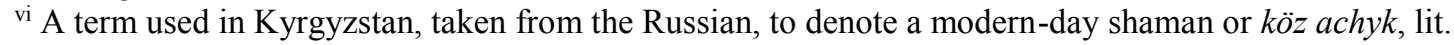
'open eye'.

vii This is paralleled in visual depictions of the epic, from Herzen's illustrations of Manas surrounded by eagles to children's drawings of him with a snow leopard in his lap.
} 